\title{
The Precondition of Benefits from IFRS Adoption: Financial Statement Comparability
}

\author{
Do Jin JUNG ${ }^{1}$, Ji An HUR ${ }^{2}$, A Reum JUNG ${ }^{3}$
}

Received: September 10, 2020 Revised: November 02, 2020 Accepted: November 05, 2020

\begin{abstract}
This study examines whether the adoption of International Financial Reporting Standards (IFRS) has increased financial statement comparability among firms and reduced undervaluation of Korean firms in the capital market by enhancing financial statement comparability. The so-called Korea Discount, which indicates an inefficient allocation of capital, has been attributed to lack of transparency and comparability of accounting information. Therefore, an efficient distribution of capital in the market was intended when IFRS was first adopted in Korea, but such progress is based on a premise of enhancement in Korean firms' accounting information comparability. This study conducts empirical analysis by using a comparability measure by De Franco et al. (2011). More specifically, it analyzes differences among comparability of domestic firms following IFRS adoption, with firms in the EU, which adopted IFRS in 2005, and with firms in the U.S., China and Japan that do not follow IFRS. The analysis of changes in domestic firms' comparability finds that their comparability improved following IFRS adoption. Meanwhile, the examination of cross-national differences in comparability demonstrates that, although there has been no significant change in comparability with firms in the U.S. and the EU across Korean industry since IFRS adoption, comparability with China has decreased while that with Japan improved.
\end{abstract}

Keywords: International Financial Reporting Standards (IFRS), IFRS Adoption, K-IFRS, Financial Statement Comparability

JEL Classification Code: G1, M4, N2

\section{Introduction}

Since the 1997 Asian Financial Crisis, in an attempt to advance its accounting system, Korea has toughened accounting supervisory and continuously reformed institutions by implementing audit review by supervising authority, increasing auditor independence, introducing internal accounting management system, and so forth. Yet, some criticize Korean firms' financial statement credibility

${ }^{1}$ First Author. Associate Professor, Accounting Department, College of Business and Economics, Chung-Ang University, Republic of Korea.Email: dj1730@cau.ac.kr

${ }^{2}$ Corresponding Author. PhD Candidate, Accounting Department, College of Business and Economics, Chung-Ang University, Republic of Korea [Postal Address: Mapo-daero 33, Mapo-gu, Seoul, 04167, Republic of Korea] Email: jian0908@daum.net

${ }^{3}$ Team Leader, Center for Social Value Enhancement Studies, Republic of Korea. Email: arjung0513@naver.com

(C) Copyright: The Author(s)

This is an Open Access article distributed under the terms of the Creative Commons Attribution Non-Commercial License (https://creativecommons.org/licenses/by-nc/4.0/) which permits unrestricted non-commercial use, distribution, and reproduction in any medium, provided the original work is properly cited. for undermining Korea by being categorized as a non-IFRS nation worldwide (Lee \& Hong, 2013). As such, in order to boost accounting information credibility by securing international coherence, Korea decided to adopt International Financial Reporting Standards (IFRS) to replace Korea Generally Accepted Accounting Principles(K-GAAP). In March of 2007, Korea Accounting Institute and IFRS Adoption Task Force released a roadmap for IFRS adoption.

In the document, the two organizations stated that the purpose of IFRS adoption was to create an opportunity to increase investor trust in Korea's accounting transparency so that Korea's accounting system could be better recognized around the world. They expected that high quality accounting information, available by IFRS adoption, would improve Korean firms' accounting information credibility, and boost comparability under the globally uniform accounting standards. Also, they predicted the adoption would help increase accounting transparency and competitiveness of domestic capital market and, as a result, resolve Korea discount (Korea Accounting Institute, 2007).

In this regard, this paper investigates whether accounting information has become more credible, comparable and 
transparent, and, in turn, Korea discount in the capital market has shrank indeed.

Many studies in Korea and overseas explore benefits and effects of IFRS adoption (Barth et al., 2008; Brochet et al., 2013; Christensen et al., 2007; DeFond et al., 2011; De Franco et al., 2011; Kwak \& Baek, 2015; Lee et al., 2012; Choi et al., 2015; Wang, 2014; Yip \& Young, 2012). Most of the literature focuses on whether IFRS adoption leads to advanced comparability or improvement in earnings quality. In Korea, especially, researchers compare local firms' comparability before and after IFRS adoption, yet they rarely make cross-border comparison.

Korea discount, which represents an inefficient allocation of capital, is blamed on the lack of transparency in accounting information. As mentioned above, enhancement in accounting information transparency and efficient distribution of capital are what Korea had in mind when adopting IFRS. Such progress, however, requires increase in credibility and comparability of Korean firms' accounting information as a precondition.

As such, this study is designed to analyze improvement of accounting information credibility and comparability step by step as it is a precondition of enhanced accounting transparency, a major benefit brought by IFRS adoption.

More specifically, we explore comparability of financial statements based on the comparability measure developed by De Franco et al. (2011). We analyze comparability at firm level and country level. We compare comparability of Korean firms after IFRS adoption with that of firms in the EU, which adopted IFRS in 2005 and with that of firms in non-IFRS countries such as the U.S., Japan and China.

\section{Literature Review}

Comparability is one of the accounting information's qualitative characteristic that allows users to identify and recognize similarities and differences in a certain category. FASB states that, while comparability is associated with uniformity, the two are not the same as the first is a goal whereas the latter helps achieve the goal. Users' decisions involve choosing between alternatives, for example, selling or holding an investment, or investing in one reporting entity or another. Consequently, information about a reporting entity is more useful if it can be compared with similar information about other entities and with similar information about the same entity for another period or another date (FASB QC21). Comparability is the qualitative characteristic that enables users to identify and understand similarities in, and differences among, items. Unlike the other qualitative characteristics, comparability does not relate to a single item. A comparison requires at least two items (FASB QC22). Consistency, although related to comparability, is not the same. Consistency refers to the use of the same methods for the same items, either from period to period within a reporting entity or in a single period across entities. Comparability is the goal; consistency helps to achieve that goal. In that sense, uniform accounting standards could boost comparability.

Not only Korea, but also countries around the world have adopted IFRS primarily to enhance cross-national comparability by using a set of integrated standards instead of depending on accounting standards that vary from country to country. As such, much research examine effects of IFRS adoption on financial statement comparability (Brochet et al., 2013; DeFond et al., 2011; De Franco et al., 2011; Kwak \& Baek, 2015; Lee et al., 2012; Choi et al., 2015; Yip \& Young, 2012)

As many of those researchers employ De Franco et al. (2011)'s comparability measure, the present study also uses the same tool. They suggested a new method that can measure firms' comparability by using firm's earnings and stock returns. Based on the measure, the researchers also examine effects of comparability on the number of financial analysts, accuracy in earnings predictability and standard deviation in earnings forecast. As a result, they find that higher financial statement comparability is related to more analysts following, greater earnings forecast accuracy and less earnings forecast standard deviation. From these findings, they suggest that better financial statement comparability lowers the cost of acquiring information and increases availability of accounting information on a firm.

Meanwhile, Brochet et al. (2013) examines whether mandatory adoption of IFRS led to enhanced financial statement comparability of British firms. They discover those British firms exhibited improved financial statement comparability following IFRS adoption, and report that the positive benefits are attributable to limits on profits through private information gained via insider trading.

Some researchers study cross-national comparability instead of focusing on the company level. Yip and Young (2012), for instance, test whether financial statement comparability among EU member countries has increased since IFRS adoption by examining comparability of firms in 17 EU countries that mandatorily adopted IFRS based on De Franco et al. (2011)'s comparability measure. Their research findings suggest that, with respect to financial statement convergence, the firms' comparability has improved following IFRS adoption, and comparability among countries that share a similar legal system has increased further. Lang et al. (2010) who use the same comparability measure developed by De Franco et al. (2011) however, produce results that are different from those of Yip and Young (2012). They examine changes in financial statement comparability by country, but cannot find a significant difference between firms that adopted IFRS and those that did not. 
DeFond et al. (2011) conducted a study with a view that countries, which implemented different accounting standards, would adopt IFRS to strengthen cross-border comparability. By checking whether foreign investors' share in mutual funds grew following IFRS adoption, they try to test comparability increase after IFRS adoption. In addition, DeFond et al. (2011) stress that comparability require the existence of accounting standard uniformity and implementation credibility. Uniformity in accounting standards is measured by counting the number of firms in the same industry that use the same accounting standards (number of firms using the same accounting methods/total number of firms). Implementation credibility is measured by examining earnings quality scores to take into account whether business managers fully implement IFRS. They confirm when both accounting standard uniformity and implementation credibility are high, that is, when comparability is high, shares owned by foreign investors increase.

Tran et al. (2020) showed that five determinants including economic, politics, law, culture, and conditions for implementation have positive relationships with the conversion of VAS (Vietnamese Accounting Standards) financial statements to IFRS. Ha and Kang (2019) analyzed the association between IFRS adjustments, measured with the IFRS reconciliations, and the subsequent meeting of target earnings. They showed meeting target earnings was associated positively with intentional IFRS adjustments for the total assets, was negatively associated with them for current assets, and was positively associated with them for non-current assets.

Cascino and Gassen (2015) investigated firms from countries with tighter reporting enforcement experience larger IFRS comparability effects, and that public firms adopting IFRS become less comparable to local GAAP private firms from the same country.

Meanwhile, Nguyen (2020) examined legal environment has the biggest effect on the harmonization process of accountingwhile on the auditors, business environment has the biggest influence. Survey on opinions of accountants and auditors shows that the application of accounting standards should not be applied to all of SMEs.

There also has been various research of IFRS adoption and comparability effect in Korea. Lee et al. (2012) explore financial statement comparability led by IFRS adoption. They examine previous literature, media reports and so forth to identify and document factors that are undermining comparability and, then, study each of those factors. As a result, the researchers find, regarding financial statement forms and representation methods, firms have different ways of calculating operating profits. Next, it is reported that, in terms of faithful representation as a precondition of comparability, it is difficult to compare operating profits and losses among firms. Finally, in a reality analysis of selection of principle-centered standards and alternative accounting system, they assume that comparability would be undermined by different decision standards of consolidated subsidiary companies.

Choi et al. (2015) analyze effects of mandatory K-IFRS adoption on comparability, and review whether it has made different effects on firms depending on their corporate governance. The researchers employ the measure that De Franco et al. (2011) developed in their study on relations between stock return and net earnings, and utilize panel data analysis model. As a result, they discover increase in comparability following mandatory K-IFRS adoption, suggesting firms in the same industry could manage their accounting in a similar manner under K-IFRS' principlecentered accounting system.

Kwak and Baek (2015) empirically verify whether K-IFRS adoption has led enhancement in cross-border comparability of local firms' financial statements. By employing the comparability measure from Barth et al. (2012)'s paper, they measure difference in domestic and foreign firms in terms of expected share prices, returns and operating cash flow. Consequently, they confirm that accounting information comparability has generally increased since K-IFRS adoption although the results somewhat differ depending on which markets and industries domestic companies belong to and what kind of legal systems paired samples comply with.

\section{Research Methods}

\subsection{Research Model and Variable Measurement}

De Franco et al. (2011) explain comparability by connecting the concept of accounting system to FASB's definition of comparability as a qualitative feature of information that allows users to recognize difference and similarity between two economic events. In other words, they consider accounting system as a mapping from economic events to financial statements and thought, for a given set of economic events, two firms have comparable accounting systems if they produce similar financial statements.

$$
\text { Financial Statements }_{i}=f\left(\text { Economic Events }_{i}\right)
$$

Based on the conceptual definition, the researchers use stock return as a proxy of net effect of an economic event, and net income as a proxy of a firm's financial statements to measure the firm's comparability.

$$
\begin{aligned}
& E(\text { Earnings })_{i i t}=\widehat{\alpha}_{i}+\widehat{\beta}_{i} \text { Return } \\
& E(\text { Earnings })_{i j t}=\widehat{\alpha_{j}}+\widehat{\beta_{j}} \text { Return }
\end{aligned}
$$


De Franco et al. (2011) attempt to measure firms' own accounting system comparability on a given economic event by assuming the individual firms' accounting systems on an economic event as $\widehat{\alpha}_{i}$ and $\widehat{\beta}_{i}, \widehat{\alpha}_{j}$ and $\widehat{\beta}_{j}$. De Franco et al. (2011), who develop a measure of comparability, use average absolute values of differences between $\mathrm{E}$ (Earnings) ${ }_{i i t}$ and E (Earnings) $)_{i j t}$ based on stock return rate and net income data over 16 quarters. For the sake of convenient interpretation, the researchers attach negativity to the values. If negative comparability measure values go down, it can be interpreted as a sign of comparability enhancement. This present study employs the same definition of accounting system and measure suggested by De Franco et al. (2011) while utilizing an equation for term-based comparable measure that Yip and Young (2012) developed to calculate time-series data of individual firms' comparability before and after IFRS adoption.

$$
\operatorname{CompAcc}_{i j t}=-\mid E(\text { Earnings })_{i i t}-E(\text { Earnings })_{i j t} \mid
$$

Equation (4) is a formula to calculate comparability of an individual firm $i$ and a specific firm $j$, and this paper measures comparability on a yearly basis as oppose to De Franco et al. (2011)'s calculation of 16 quarter-based comparability. Meanwhile, they use median comparability measure for all firms in the same industry (CompAccInd) and average for the four highest comparability measure values (CompAcc4) as values that could represent firm i's comparability measure, and this study performs analyses by employing the same values as theirs.

In this comparability research, we first examine improvement in local firms' comparability following IFRS adoption, and, then, explore enhancement in comparability with firms overseas. Firms subject to the comparability analyses are from the same industry categorized by GICS code.

The first step of comparability research is to analyze differences in comparability following IFRS adoption in Korea, and for the purpose of this analysis, we develop the following model.

H1. There is no difference between before and after IFRS adoption in financial statement comparability among Korean firms.

$$
\text { where, }
$$$$
\text { CompAcc }=\beta_{0}+\beta_{1} I F R S+\beta_{2} S I Z E_{t}+\beta_{3} L E V_{t}+\beta_{4} M T B_{t}
$$

$$
+\beta_{5} R E T V O L+\Sigma I N D+\varepsilon_{t}
$$

CompAcc: Comparability measure of De Franco, Kothari and Verdi(2011)

- CompAcc4: Average of the four highest CompAcc values among pairs in the same industry

- CompAccInd: Median CompAcc for all firms in the same industry

IFRS: 1 if after IFRS adoption or 0 otherwise
SIZE: Natural logarithm of aggregate underlying assets LEV: Leverage ratio

MTB: Market capitalization divided by book value

RETVOL: Stock return rate volatility (Standard deviation of monthly rate of return $* 1 / \sqrt{12}$ )

$\Sigma I N D$ : Industry effect

CompAcc is the comparability measure developed by De Franco et al. (2011) and, we especially use average of the four highest CompAcc values in the same industry (CompAcc4) and median CompAcc for all firms in the same industry (CompAccInd). IFRS in Equation (5) is a variable that indicates whether it's a pre- or post- IFRS adoption period. Since Korea made IFRS implementation mandatory in 2011, 2011 and following years are represented as 1 and years that precede 2010 as 0 . SIZE represents a firm's total asset size, measured in natural logarithm of its aggregate underlying assets. LEV is leverage ratio while MTB, or Market to Book ratio is market capitalization divided by total book value. RETVOL is a variable that controls a firm's monthly return rate volatility and is calculated by multiplying standard deviation of an individual firm's monthly return rate by $1 / \sqrt{12}$. Also, we categorize industries based on GICS code and set an industry indicator variable.

In the second step of our comparability study, we investigate whether Korean firms' comparability with foreign counterparts has improved since IFRS adoption. As such, we analyze the following model.

H2. There is no difference between Korean and foreign firms in financial statement comparability from IFRS adoption.

$$
\begin{aligned}
\text { CompAcc }= & \beta_{0}+\beta_{1} I F R S+\beta_{2} S I Z E_{t}+\beta_{3} L E V_{t}+\beta_{4} M T B_{t} \\
& +\beta_{5} \text { NUMLIST }+\beta_{6} \text { XLIST }+\beta_{7} L E G A L \\
& +\beta_{8} \text { RETVOL }+\Sigma I N D+\varepsilon_{t}
\end{aligned}
$$

where,

CompAcc: Comparability measure of De Franco, Kothari and $\operatorname{Verdi}(2011)$

- CompAcc4: Average of the four highest CompAcc values among pairs in the same industry

- CompAccInd: Median CompAcc for all firms in the same industry

IFRS: 1 if after IFRS adoption or 0 otherwise

SIZE: Natural logarithm of aggregate underlying assets

LEV: Leverage ratio

MTB: Market capitalization divided by book value

NUMLIST: Number of exchanges listing the firm in question

XLIST: 1 if a firm is cross-listed in a U.S. exchange, or 0 if not

LEGAL: 1 if a country follows the code law system, or 0 if not 
RETVOL: Stock return rate volatility (Standard deviation of monthly rate of return $* 1 / \sqrt{12}$ )

$\Sigma I N D$ : Industry effect

We apply CompAcc4 and CompAccInd for crossnational analysis just like our analysis of domestic firms' comparability. While using the same variables of IFRS, SIZE, LEV and MTB, we add some of the control variables that previous literature utilize to examine cross-border comparability legal system (LEGAL), number of exchanges where a firm is listed (NUMLIST) and whether a firm is cross-listed at a U.S. exchange (XLIST). LEGAL is a variable that indicates which legal system a firm's country follows. 1 means the country obeys code laws, 0 common laws. NUMLIST is the number of exchanges where the firm in question is listed, and XLIST is an indicator variable, which is 1 for a firm listed in a U.S. exchange or 0 for a firm not listed in the U.S. To categorize industries, we apply GICS code and develop an industry indicator variable to control industry-specific effects.

\subsection{Sample Selection}

BUREAU VAN DIJK OSIRIS Database is the source of data used in this study, which are collected from a total of
5,483 firms (49,347 firm-year) in EU member countries, the U.S., Japan, China and Korea from 2006 to 2014, excluding those that are described below. Some domestic research which developed a comparability measure included same fiscal reporting time. But Fama and French (1992) found out the gap of reporting time did not make significant impacts on test results, so we included all firms that satisfied 4 conditions below.

[1]. Among 28 members of the EU, countries that joined the organization after it adopted IFRS in 2005 (Croatia, Bulgaria and Romania) are excluded.

[2]. Firms from financial sector such as banks, insurers and real estate firms(those that fall under GICS code 40-Financial Sector: Banks, Diversified Financials, Insurance, Real Estate) are excluded.

[3]. Among firms in non-IFRS countries (the U.S., China and Japan), those that voluntarily adopted IFRS are excluded.

[4]. Firms which have missing value are excluded.

Table 2 presents descriptive statistics of major variables used in analysis on each sample country. As most of the variables are found to be skewed, failing to meet the requirement of normality, we winsorize all of them at $90 \%$ level.

Table 1: Sample composition

\begin{tabular}{|c|c|c|c|c|c|c|}
\hline \multicolumn{7}{|c|}{ Panel A : Sample composition by country } \\
\hline Observations & $\mathrm{CN}$ & EU & $\mathrm{JP}$ & $\mathrm{KR}$ & US & Total \\
\hline Number of Firms & 363 & 1,477 & 1,864 & 448 & 1,331 & 5,483 \\
\hline$\%$ of Firms & 6.62 & 26.94 & 34.00 & 8.17 & 24.28 & 100 \\
\hline Firm-Year Observations & 3,267 & 13,293 & 16,776 & 4,032 & 11,979 & 49,347 \\
\hline \multicolumn{7}{|c|}{ Panel B : Sample composition by industry } \\
\hline Industry(code) & $\mathrm{CN}$ & EU & $\mathrm{JP}$ & $\mathrm{KR}$ & US & Total \\
\hline Energy(10) & 6 & 45 & 17 & 5 & 100 & 173 \\
\hline Materials(15) & 73 & 138 & 220 & 99 & 98 & 628 \\
\hline Industrials(20) & 97 & 411 & 600 & 99 & 268 & 1,475 \\
\hline Consumer Discretionary(25) & 69 & 317 & 460 & 93 & 261 & 1,200 \\
\hline Consumer Staples(30) & 30 & 139 & 168 & 33 & 79 & 449 \\
\hline Health Care(35) & 28 & 88 & 61 & 30 & 173 & 380 \\
\hline Information Technology(45) & 38 & 262 & 314 & 78 & 281 & 973 \\
\hline Telecommunication Services(50) & 1 & 28 & 3 & 3 & 9 & 44 \\
\hline Utilities(55) & 21 & 49 & 21 & 8 & 62 & 161 \\
\hline Total & 363 & 1,477 & 1,864 & 448 & 1,331 & 5,483 \\
\hline
\end{tabular}


Table 2: Descriptive Statistics

\begin{tabular}{|c|c|c|c|c|c|c|}
\hline Country & $\mathbf{N}$ & Variable & Mean & Std. & Max. & Min. \\
\hline \multirow{8}{*}{$\mathrm{KR}$} & \multirow{8}{*}{4,032} & SIZE & 19.555 & 1.616 & 23.148 & 17.364 \\
\hline & & LEV & 1.439 & 1.290 & 5.032 & 0.169 \\
\hline & & MTB & 1.069 & 0.767 & 3.180 & 0.279 \\
\hline & & RETVOL & 0.038 & 0.018 & 0.081 & 0.015 \\
\hline & & NUMLIST & 1.004 & 0.067 & 2.000 & 1.000 \\
\hline & & XLIST & 0.004 & 0.067 & 1.000 & 0.000 \\
\hline & & Comp_Ind & -0.046 & 0.027 & -0.018 & -0.122 \\
\hline & & Comp4 & -0.005 & 0.008 & 0.000 & -0.031 \\
\hline \multirow{8}{*}{ US } & \multirow{8}{*}{11,979} & SIZE & 20.325 & 1.919 & 23.981 & 17.194 \\
\hline & & LEV & 1.337 & 1.240 & 4.858 & 0.126 \\
\hline & & MTB & 2.244 & 1.890 & 7.661 & 0.335 \\
\hline & & RETVOL & 0.033 & 0.016 & 0.072 & 0.012 \\
\hline & & NUMLIST & 3.248 & 2.554 & 16.000 & 1.000 \\
\hline & & XLIST & 0.701 & 0.458 & 1.000 & 0.000 \\
\hline & & Comp_Ind & -0.065 & 0.050 & -0.021 & -0.218 \\
\hline & & Comp4 & -0.014 & 0.025 & 0.000 & -0.101 \\
\hline \multirow{8}{*}{ EU } & \multirow{8}{*}{13,293} & SIZE & 19.989 & 1.955 & 24.054 & 17.086 \\
\hline & & LEV & 1.678 & 1.375 & 5.498 & 0.216 \\
\hline & & MTB & 1.691 & 1.371 & 5.472 & 0.273 \\
\hline & & RETVOL & 0.032 & 0.015 & 0.068 & 0.013 \\
\hline & & NUMLIST & 3.705 & 3.367 & 17.000 & 1.000 \\
\hline & & XLIST & 0.164 & 0.370 & 1.000 & 0.000 \\
\hline & & Comp_Ind & -0.052 & 0.036 & -0.021 & -0.158 \\
\hline & & Comp4 & -0.008 & 0.014 & 0.000 & -0.055 \\
\hline \multirow{8}{*}{$\mathrm{CN}$} & \multirow{8}{*}{3,267} & SIZE & 19.843 & 1.461 & 22.880 & 17.540 \\
\hline & & LEV & 1.500 & 1.268 & 4.947 & 0.183 \\
\hline & & MTB & 1.585 & 1.385 & 5.382 & 0.247 \\
\hline & & RETVOL & 0.038 & 0.016 & 0.077 & 0.017 \\
\hline & & NUMLIST & 1.189 & 0.928 & 9.000 & 1.000 \\
\hline & & XLIST & 0.022 & 0.147 & 1.000 & 0.000 \\
\hline & & Comp_Ind & -0.007 & 0.043 & 0.064 & -0.096 \\
\hline & & Comp4 & -0.002 & 0.008 & 0.011 & -0.027 \\
\hline \multirow{8}{*}{ JP } & \multirow{8}{*}{16,776} & SIZE & 19.973 & 1.480 & 23.093 & 17.655 \\
\hline & & LEV & 1.439 & 1.211 & 4.654 & 0.193 \\
\hline & & MTB & 1.034 & 0.651 & 2.774 & 0.315 \\
\hline & & RETVOL & 0.030 & 0.014 & 0.065 & 0.012 \\
\hline & & NUMLIST & 1.573 & 1.441 & 13.000 & 1.000 \\
\hline & & XLIST & 0.061 & 0.239 & 1.000 & 0.000 \\
\hline & & Comp_Ind & -0.036 & 0.018 & -0.016 & -0.087 \\
\hline & & Comp4 & -0.003 & 0.004 & 0.000 & -0.018 \\
\hline
\end{tabular}




\section{Results}

Hypothesis 1 is established to test whether comparability of Korean firms has enhanced since the mandatory IFRS adoption. As such, we develop balanced panel data on 448 local firms (4,032 firm-year). After grouping firms which belong to nine different industries except for financial enterprises (GICS code 40 ) into a total of $448 * 448$ pairs, we calculate Equation (4) for all the pairs.

Then, we measure Comp_Ind with median values of each industry and Comp4 with the four highest values within the industries. Although not presented in the table, comparability measure for each year finds that Comp4 values are considerably less than Comp_Ind at 10\% level throughout all years subject to analysis andthis result supports the general idea that firms have different comparability even they are in the same industry.

Table 3 presents results of t-test performed on Comp_Ind and Comp4 from before and after IFRS adoption in 2011 in order to verify whether there has been a significant change in comparability measure since IFRS adoption. Decrease in comparability measure confirmed through Equation (4) indicates comparability has improved since IFRS was adopted in Korea.

Figures shown in Panel A are mean differences in comparability between before and after IFRS adoption, calculated by subtracting mean values in the pre-adoption period from those in the post-adoption period. The difference in Comp_Ind prior to and following IFRS adoption is 0.002 , indicating a increase has been made in comparability measure significantly after the adoption. Comp4, however, has rarely changed since IFRS adoption and recorded low significance level failing to demonstrate a significant difference as Comp_Ind does.

Panel B presents results of analysis on Comp-Ind difference before and after IFRS adoption that is performed to see whether the increase in Comp-Ind varied in different industries. In the case of IT industry, comparability has declined by a significant degree, whereas that within health care industry, including biotechnology sector,has demonstrated a significant increase since IFRS adoption.

We conduct panel data analysis to examine comparability between firms has increased since IFRS adoption (Hypothesis 1) even when we control changes in the capital market as well as in a specific industry, corporate characteristics, and so forth. As Hausman test rule out null hypothesis of random effect at $1 \%$ level of significance, we perform regression analysis based on fixed effect model.

Table 4 presents results of panel data analysis on the hypothesis. $\beta_{1}$, which represents comparability change following IFRS adoption, do not suggest a significant difference in comparability of the industry on average (coefficient at -0.001, t-value at -1.340).Meanwhile, average of the four highest comparability measure values in the same industry (Comp4) turns out to have lowered at 1\% level of significance since IFRS adoption.

In the second comparability analysis on cross-national difference, we test whether IFRS adoption has led a difference in comparability with foreign firms. More specifically, we examine EU member countries that adopted IFRS, as well as the U.S., Japan and China, non-IFRS nations, to analyze if there is a difference between comparability of Korean companies and that of firms in those countries.

Table 3: Descriptive Statistics of Comparability Proxies (Korea subsample)

\begin{tabular}{|c|c|c|c|c|}
\hline \multicolumn{5}{|c|}{ Panel A. Before \& After IFRS Adoption } \\
\hline \multicolumn{2}{|l|}{ Mean } & Pre-IFRS & Post-IFRS & Difference \\
\hline \multicolumn{2}{|l|}{ comp_ind } & -0.047 & -0.044 & $0.002^{* * *}$ \\
\hline \multicolumn{2}{|l|}{ comp4 } & -0.005 & -0.005 & $0.000^{*}$ \\
\hline \multicolumn{5}{|c|}{ Panel B. Comparability proxy(comp_ind) by industry } \\
\hline \multicolumn{3}{|c|}{ Industry code } & $\mathbf{N}$ & Difference \\
\hline 10 & \multicolumn{2}{|l|}{ Energy } & 45 & 0.002 \\
\hline 15 & \multicolumn{2}{|c|}{ Materials } & 891 & $0.010^{* * *}$ \\
\hline 20 & \multicolumn{2}{|c|}{ Industrials } & 891 & 0.000 \\
\hline 25 & \multicolumn{2}{|c|}{ Consumer Discretionary } & 837 & -0.001 \\
\hline 30 & \multicolumn{2}{|c|}{ Consumer Staples } & 297 & $0.009^{* * *}$ \\
\hline 35 & \multicolumn{2}{|c|}{ Health Care } & 270 & $0.013^{* * *}$ \\
\hline 45 & \multicolumn{2}{|c|}{ Information Technology } & 702 & $-0.006^{* * *}$ \\
\hline 50 & \multicolumn{2}{|c|}{ Telecommunication Services } & 27 & 0.002 \\
\hline 55 & \multicolumn{2}{|l|}{ Utilities } & 72 & -0.002 \\
\hline
\end{tabular}


Table 4: Results of Hypothesis 1

\begin{tabular}{|c|c|c|c|}
\hline \multicolumn{4}{|c|}{ 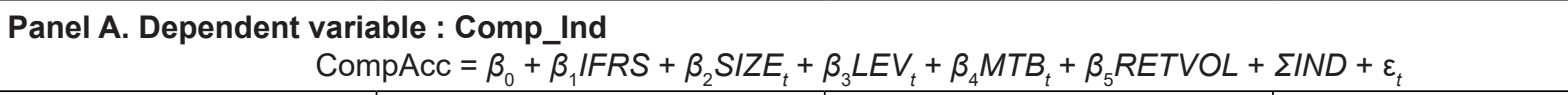 } \\
\hline variables & Estimate & S.E. & t-value \\
\hline IFRS & -0.001 & 0.001 & -1.340 \\
\hline SIZE & 0.010 & 0.001 & $8.880^{\star * *}$ \\
\hline LEV & -0.003 & 0.000 & $-5.640^{* * *}$ \\
\hline MTB & -0.003 & 0.001 & $-5.240^{\star * \star}$ \\
\hline RETVOL & 0.001 & 0.020 & 0.060 \\
\hline Industry effect & \multicolumn{3}{|c|}{ Included } \\
\hline $\mathrm{R}^{2}$ & \multicolumn{3}{|c|}{0.612} \\
\hline $\mathrm{F}$ & \multicolumn{3}{|c|}{12.53} \\
\hline \multicolumn{4}{|c|}{ Panel B. Dependent variable : Comp4 } \\
\hline variables & Estimate & S.E. & t-value \\
\hline IFRS & -0.001 & 0.000 & $-2.750^{* * *}$ \\
\hline SIZE & 0.003 & 0.000 & $8.250^{* * *}$ \\
\hline LEV & -0.001 & 0.000 & $-5.320^{* * \star}$ \\
\hline MTB & -0.001 & 0.000 & $-3.660^{* * *}$ \\
\hline RETVOL & -0.008 & 0.006 & -1.380 \\
\hline Industry effect & \multicolumn{3}{|c|}{ Included } \\
\hline $\mathrm{R}^{2}$ & \multicolumn{3}{|c|}{0.603} \\
\hline $\mathrm{F}$ & \multicolumn{3}{|c|}{12.04} \\
\hline \multicolumn{4}{|c|}{$\begin{array}{l}\text { Note : }{ }^{* * *},{ }^{* *} \text {, and }{ }^{*} \text { each represents significance level at } 1 \%, 5 \% \text { and } 10 \% \text { (two-sided test). } \\
\text { Panel A: CompAcc_Ind, median CompAcc in the same industry as dependent variable } \\
\text { Panel B: Comp4, average of the four highest CompAcc values in the same industry, as dependent variable }\end{array}$} \\
\hline
\end{tabular}

For analysis of firms' comparability change in each country, we establish four subsamples. As our focus is on Korean firm's comparability with foreign firms, we form subsamples around Korea such as Korea-Europe, Koreathe U.S., Korea-China and Korea-Japan, pair similar firms in the same industry for each country, and calculate their comparability for the analysis.

As proxies of comparability for cross-national comparability analysis, we utilize Comp_Ind and Comp4, same as we do for the analysis on local firms. We form pairs of firms that are categorized in the same industry based on GICS code. For instance, 99 firms in Korea fall under GICS code 20 (Industrials). Among those 99, firm i's comparability with 271 U.S. firms in the same industry (20) is measured through Equation (4). For example, to measure comparability of Korean and the U.S. firms that belong to GICS code 20, 26,829(99*271) operations are need to be done. The median value of the industry is presented as Comp-Ind and average of the four highest values, Comp4.

As shown in Table 5, Korean firms' comparability with US firms has not made a significant change across the industry (Comp_Ind) after IFRS adoption. Yet, among four most comparable companies in the same industry, comparability has enhanced since IFRS adoption in Korea. There is no indication that comparability with firms in the EU has significantly improved across the industry, and no significant change is found among the most comparable firms in the same industry after IFRS adoption.

On the other hand, comparability with Japanese firms has improved since IFRS adoption, and, the same improvement is confirmed when examined with Comp_Ind and Comp4. Meanwhile, comparability with Chinese firms is found to have decreased since IFRS adoption. When Comp_Ind and Comp 4 values are employed, comparability also turns out to have lowered at a significant level. 
Table 5: Results of Hypothesis 2

\begin{tabular}{|c|c|c|c|c|}
\hline \multicolumn{5}{|c|}{$\begin{array}{l}\text { Panel A. Dependent variable : Comp_Ind } \\
\qquad \text { CompAcC }=\beta_{0}+\beta_{1} I F R S+\beta_{2} S I Z E_{t}+\beta_{3} L E V_{t}+\beta_{4} M T B_{t}+\beta_{5} N U M L I S T_{t}+\beta_{6} X L I S T+\beta_{7} L E G A L+\beta_{8} R E T V O L+\Sigma I N D+\varepsilon_{t}\end{array}$} \\
\hline Variables & US & EU & CN & JP \\
\hline IFRS & 0.000 & 0.000 & $-0.001^{* *}$ & $0.002^{* * *}$ \\
\hline SIZE & $0.003^{* * *}$ & $0.002^{* * *}$ & $0.002^{* * *}$ & $0.001^{* * *}$ \\
\hline LEV & $0.001^{* * *}$ & $-0.001^{* * *}$ & $-0.001^{* * *}$ & $-0.001^{* * *}$ \\
\hline MTB & $-0.002^{* * *}$ & $0.000^{* *}$ & $0.000^{* * *}$ & $-0.001^{* * *}$ \\
\hline RETVOL & $-0.069^{* * *}$ & $-0.069^{* * *}$ & 0.004 & -0.010 \\
\hline NUMLIST & \multicolumn{4}{|c|}{ Included } \\
\hline XLIST & \multicolumn{4}{|c|}{ Included } \\
\hline LEGAL & \multicolumn{4}{|c|}{ Included } \\
\hline Industry effect & \multicolumn{4}{|c|}{ Included } \\
\hline $\mathrm{R}^{2}$ & 0.826 & 0.799 & 0.912 & 0.712 \\
\hline $\mathrm{F}$ & 37.81 & 31.76 & 82.62 & 19.75 \\
\hline \multicolumn{5}{|c|}{ Panel B. Dependent variable : Comp4 } \\
\hline Variables & US & EU & $\mathrm{CN}$ & JP \\
\hline IFRS & $0.0013^{* * *}$ & 0.0001 & $-0.0004^{* *}$ & $0.0003^{* * *}$ \\
\hline SIZE & $-0.0007^{* * \star}$ & $0.0005^{* *}$ & $0.0011^{* * *}$ & $0.0003^{* * *}$ \\
\hline LEV & $-0.0004^{* *}$ & $-0.0002^{* * *}$ & $-0.0004^{* * *}$ & $-0.0001^{* * *}$ \\
\hline MTB & $0.0002^{* * *}$ & 0.0000 & $-0.0001^{* *}$ & $-0.0001^{*}$ \\
\hline RETVOL & $-0.0350^{* * *}$ & $-0.0284^{* * *}$ & -0.0013 & $-0.0030^{*}$ \\
\hline NUMLIST & \multicolumn{4}{|c|}{ Included } \\
\hline XLIST & \multicolumn{4}{|c|}{ Included } \\
\hline LEGAL & \multicolumn{4}{|c|}{ Included } \\
\hline Industry effect & \multicolumn{4}{|c|}{ Included } \\
\hline $\mathrm{R}^{2}$ & 0.837 & 0.815 & 0.764 & 0.693 \\
\hline $\mathrm{F}$ & 41.02 & 35.22 & 25.76 & 18.02 \\
\hline
\end{tabular}

As results in Table 5 demonstrate, while there is little evidence on improved comparability across the industry, comparability turns out to have enhanced among highly comparable firms. To identify whether such results are attributable to inter-corporate characteristics, we perform an additional analysis on firms in Korea and the U.S. We employ propensity score matching to compare Korean firms with ones with similar corporate features in the U.S.

$$
\begin{aligned}
\operatorname{Pr}\left(D_{i}=1 \mid X_{i}\right)= & \alpha_{0}+\alpha_{1} S_{Z I Z E_{t}}+\alpha_{2} L E V_{t}+\alpha_{3} M T B_{i} \\
& +\alpha_{4} R E T V O L_{i}+\alpha_{5} I N D_{i}+\alpha_{6} R O A_{i}+\varepsilon_{i}
\end{aligned}
$$

Equation (7) is formulated to calculate propensity scores. In logistic regression analysis whose dependent variable is indicator variable that is 1 if it's a Korean firm, or 0 if not, we form one-on-one pairs of Korean and U.S. firms under quasiexperimental circumstances and try to eliminate selection bias arising from selection of matching firms. Based on propensity scores produced from the regression analysis on Equation (7), we match 256 similar firms with a caliper at 0.05 , while matching 146 different firms with a caliper at 0.7 . We limit the caliper for similar firm selection within a 5\% range and while limiting that for different firms at $95 \%$. Since we find only two firms are matched, we loosen the caliper for different firms to 0.7 to include more firms for analysis. Finally, we examine the consequent subsamples of Korean and U.S. firms with similar and different propensities and analyze whether they have experienced comparability changes since IFRS adoption. 
Table 6: Comparability effect: Similar firms vs. Different firms

\begin{tabular}{|c|c|c|c|c|}
\hline \multicolumn{5}{|c|}{ CompAcc $=\beta_{0}+\beta_{1} I F R S+\beta_{2} S I Z E_{t}+\beta_{3} L E V_{t}+\beta_{4} M T B_{t}+\beta_{5} N U M L I S T_{t}+\beta_{6} X L I S T+\beta_{7} L E G A L+\beta_{8} R E T V O L+\Sigma I N D+\varepsilon_{t}$} \\
\hline \multirow{2}{*}{ variables } & \multicolumn{2}{|c|}{ Similar firms } & \multicolumn{2}{|c|}{ Different firms } \\
\hline & Estimate & t-value & Estimate & t-value \\
\hline IFRS & -0.0051 & $-2.49^{* *}$ & -0.00367 & -0.53 \\
\hline SIZE & 0.0012 & 0.31 & 0.005793 & 0.52 \\
\hline LEV & -0.0003 & -0.17 & 0.003746 & 0.77 \\
\hline MTB & 0.0015 & 1.35 & 0.006876 & $1.99^{* *}$ \\
\hline RETVOL & 0.0096 & 0.14 & -0.00946 & -0.04 \\
\hline NUMLIST & \multicolumn{4}{|c|}{ Included } \\
\hline XLIST & \multicolumn{4}{|c|}{ Included } \\
\hline LEGAL & \multicolumn{4}{|c|}{ Included } \\
\hline Industry effect & \multicolumn{4}{|c|}{ Included } \\
\hline $\mathrm{N}$ & \multicolumn{2}{|c|}{4,608} & \multicolumn{2}{|c|}{2,628} \\
\hline $\mathrm{R}^{2}$ & \multicolumn{2}{|c|}{0.644} & \multicolumn{2}{|c|}{0.649} \\
\hline $\mathrm{F}$ & \multicolumn{2}{|c|}{14.32} & \multicolumn{2}{|c|}{14.53} \\
\hline \multicolumn{5}{|c|}{$\begin{array}{l}* * *, * * \text { and }{ }^{*} \text { each represents significance level at } 1 \%, 5 \% \text { and } 10 \% \text { (two-sided test). } \\
\text { Panel A: Results of one-on-on matching between Korean and the U.S. firms based on Propensity Score Matching. Caliper of } 0.05 \text { and } \\
\text { caliper of } 0.7 \text { are applied for similar and different firms, respectively. If inter-firm difference is within a } 5 \% \text { range, firms are regarded as } \\
\text { similar. If the difference is } 70 \% \text { or greater, the firms are considered different for } 1: 1 \text { matching. Comparability of matched firms is calculated } \\
\text { by Equation (4). }\end{array}$} \\
\hline
\end{tabular}

We measure comparability of one-on-one matched firms via Equation (4) and conduct regression analysis through Equation (6), whose results are presented in Table 6. According to the results, comparability with U.S. firms that are similar to Korean firms has declined at a significant level since IFRS adoption, whereas comparability with companies that have different corporate properties does not show a significant difference. When interpreted in connection with the results in Table 5, it means increased comparability across the industry is not driven by enhancement in comparability among firms with similar corporate characteristics. In other words, it implies the results - no big difference in comparability within the industry, but improvement in comparability among highly comparable firms- are not attributable to specific firms.

\section{Conclusion}

Benefits of IFRS adoption in Korea including decrease in undervaluation of Korean firms (so-called Korea discount) are based upon a premise of advanced financial statement comparability among firms. This paper examines, in the perspective of information users, the existence of enhanced comparability in the capital market as a precondition of IFRS adoption.

We employ the comparability measure developed by De Franco et al. (2011) to conduct an analysis of cross-national comparability. More specifically, we examine if Korean firms' comparability following IFRS adoption is different from that of firms in the EU, which adopted IFRS in 2005 and from that of firms in the U.S., Japan and China, nonIFRS countries.

Analysis of changes in comparability of Korean enterprises after IFRS adoption suggests comparability within the same industry increased after IFRS adoption. The analysis of cross-national comparability differences, however, finds little evidence of enhanced comparability with firms in the U.S. and the EU. Still, comparability with Chinese as well as Japanese firms turns out to be reduced following IFRS adoption. Since analysis of comparability with U.S. firms produces different results from what we find with Comp_Ind and Comp4, we conduct an additional analysis by applying propensity score matching method. As a result, we find that there has been no improvement in comparability with U.S. firms that share similar corporate propensities after IFRS adoption in Korea. It implies that 
comparability improvement of Comp4 is not driven by similar firms.

When adopting IFRS, Korea intended to ease the phenomenon of Korea discount by securing international comparability. However, improvement of undervaluation of Korean stocks through international comparability presupposes enhancement in comparability with other countries. As such, this study looks into comparability, a precondition of IFRS adoption-led benefits, instead of simply analyzing correlation between IFRS adoption and accounting numbers. Most of research studied effects of IFRS adoption on cross-country comparability largely focus on the European Union, and most of previous research categorize Korea as a non-IFRS nation. In addition, while there is a number of papers that examine Korean firms' comparability following IFRS adoption, little research has been done to analyze comparability differences among various nations over a long term. In this regard, we believe new insights could be brought by this paper.

\section{References}

Barth, M., Landsman, W., \& Lang, M. (2008). International accounting standards and accounting quality. Journal of Accounting Research, 46(3), 467-498.

Barth, M., Landsman, W., Lang, M., \& Williams, C. (2012). Are IFRS-based and US GAAP-based accounting amounts comparable? Journal of Accounting and Economics, 54(1): 68-93.

Brochet, F., Jagolinzer, A., \& Riedl, E. (2013). Mandatory IFRS Adoption and Financial Statement Comparability. Contemporary Accounting Research, 30(4), 1373-1400.

Cascino, S., \& Gassen, J. (2015). What drives the comparability effect of mandatory IFRS adoption? Review of Accounting Studies, 20(1), 242-282.

Choi, Y. S., Yang, D. H., \& Cho, K. H. (2015). Impact of Mandatory K-IFRS Adoption on Accounting Comparability in the Same Industry - Focusing on the Differences of the Corporate Governance Characteristics. Journal of Accounting, 24(6), 235-276.

Christensen, H. B., Lee, E., \& Walker, M. (2007). Cross-sectional variation in the economic consequences of international accounting harmonization: The case of mandatory IFRS adoption in the UK. International Journal of Accounting, 42(4), 341-379.

DeFond, M., Hu, X., Hung, M., \& Li, S. (2011). The impact of mandatory IFRS adoption on foreign mutual fund ownership:
The role of comparability. Journal of Accounting and Economics, 51(3), 240-258.

De Franco, G., Kothari, S. P., \& Verdi, R. S. (2011). The benefits of financial statement comparability. Journal of Accounting Research, 49(4), 895-931.

Fama, E., \& French, K. (1992). The Cross-Section of Expected Stock Returns. The Journal of Finance, XLVII(2).

Ha, M. H., \& Kang, M. J. (2019). IFRS Reconciliation Adjustment and Subsequent Meet or Beat Target Earnings. Journal of Asian Finance, Economics and Business, 6(1), 33-45. http://doi. org/10.13106/jafeb.2019.vol6.no1.33

Kim, Y. H. (2007). Roadmap toward IFRS Adoption in Korea. In: Proceedings of IFRS Adoprtion Announcement of Korea Accounting Institute (pp. 6-16). Seoul. Republic of Korea. March 15. Seoul, Korea: KAI Publishing.

Kwak, Y. M., \& Baek, J. H. (2015).K-IFRS Adoption, Accounting Comparability between Korean Firms and Foreign Firms. Accounting Information Research, 33(3), 55-83.

Lang, M. H., Maffett, M. G., \& Owens, E. L. (2010). Earnings Comovement and Accounting Comparability: The Effects of Mandatory IFRS Adoption. In SSRN Electronic Journal. https://doi.org/10.2139/ssrn.1676937

Lee, H. Y., Kang, M. J., Jang, K. J., \& Lee, H. S. (2012). An Analysis on Comparability of Financial Statements after IFRS Adoption. Journal of Accounting, 21(3), 307-342.

Lee, Y. S., \& Hong, J. H. (2013).K-IFRS Adoption and Quality of Accounting Income - Comparison of Companies that Adopted K-IFRS in Advance and Companies Subject to Mandatory K-IFRS Adoption. International Accounting Research, 47(2), 197-228.

Nguyen, D. D. (2020). The Impact of Environmental Factors on the International Harmonization Process of Accounting on SMEs: Evidence in Vietnam. Journal of Asian Finance, Economics and Business, 7(10), 641-649. https://doi.org/10.13106/jafeb.2020. vol7.no10.641

Tran, M. D., Ngo, T. T. M., Phan, T. U., Do, D. T., \& Pham, T. T. H. (2020). Determinants Influencing the Conversion of Financial Statements: The Case of Multinational Firms in Vietnam. Journal of Asian Finance, Economics and Business, 7(3), 17-27. https://doi.org/10.13106/jafeb.2020.vol7.no3.17

Wang, C. (2014). Accounting Standards Harmonization and financial statement comparability: Evidence from Transnational information transfer. Journal of Accounting Research, 52(4), 955-992.

Yip, R., \& Young, D. (2012). Does mandatory IFRS adoption improve information comparability? Accounting Review, 87(5), 1767-1789. 